\title{
AJIL AT 111
}

The American Journal of International Law (AJIL) was launched in January 1907, under the editorship of the indefatigable James Brown Scott, in tandem with the founding of the American Society of International Law (ASIL). After 110 years of being self-published by ASIL, AJIL has embarked on a new era. Starting with this issue, AJIL will be published by Cambridge University Press (CUP). This note is about the transitions AJIL has so far undertaken, both in print and in cyberspace. We sketch some of the changes that have taken place since we assumed the joint editor in chief role in April 2013, and highlight some possibilities for the future, as an invitation to AJIL readers to comment on the changes made and on changes they would like to see utilizing the new technological platform and taking account of shifts in the demography, interests, and needs of practitioners, scholars, and students in all fields concerned with international law. Editorial changes to a publication concerned with public international law should also be informed by different views on changes occurring in the field itself, and we begin with a brief reference to some of these.

In the 1990s, with some of the constraints of the Cold War division lifted and new political dynamics in many countries and regions, a wide array of ambitious international legal projects surged forward on a liberal tide, energizing young people and bringing new horizons for expanding legal elites. This spirit echoed and updated the hopeful sentiments which, in the early 1900s, animated some participants in the establishment of ASIL, including former U.S. Secretary of State Elihu Root, who took an active role in the Society's founding. In the early 1990s some members of ASIL talked of a "new world order" with reinvigorated UN peacekeeping and resurgent regional and global institutions. It was thought that these changes might at last bring to fruition the legalistic goals foreshadowed by successive generations, including Root and his colleagues, as well as those who in the 1940s were "present at the creation" of the UN system. A veto-free UN Security Council might "finally work as intended" to deliver collective security — not only to defend Kuwait against outright invasion, but to protect states and peoples against many kinds of threats. By 1994, the Uruguay Round had transformed a somewhat frail General Agreement on Tariffs and Trade into the thoroughly reformed World Trade Organization (WTO), with compulsory and binding interstate dispute settlement. War crimes tribunals were established, remarkably, by UN Security Council fiat. In the years following, those innovative adjudicative mechanisms were joined by over twenty other new international courts or tribunals—a period of "judicialization" that led to a new interest in the capacity of law to restrain, or at least influence, nations, including, notably, among political scientists. One of us came to describe the new patterns of governance as having the markings of "global administrative law," while others, particularly in Europe, deployed a more general "international public law" frame. Scholaradvocates wrote hopefully of further reforms to international regimes to advance not simply "legalization," or even "constitutionalization," but an aggregate of attributes that together 
would effectuate the international rule of law, while international institutions like the United Nations and the World Bank, would promote and deepen national "good governance" in pursuit of comparable ends.

In 2017 that era seems long gone. Characterizations such as "authoritarian," "populist," and "illiberal democracy," imprecise or reductionist as they often are, now attach to governmental styles in many great and medium powers. Tensions involving major powers are increasingly widespread and recurrent. United Kingdom voters and their government have opted for an eventual British exit from the European Union, and the EU faces other significant internal and external difficulties. A U.S. president, elected amidst a popular rejection of some standard North Atlantic political positions, has signaled some resistance to many international organizations and regimes, and other electorates may follow. Economic might and geopolitical power have shifted, and the era of North Atlantic dominance has given way to a more diffuse distribution and a massive growth in activity and power in Asia, particularly power now deployable by China. While "globalization" continues with little abatement in many fields, prevailing attitudes toward globalization and forms of international legalization and judicialization have in many places become nuanced, conflicted, and sometimes strongly oppositional.

Opposition to international institutions or assertive international legal action is by no means universal. Some of it is opportunistic. In some cases, such as opposition to the International Criminal Court (ICC) within Africa, the backlash is largely (but not entirely) regional; in others, such as the controversies associated with electing WTO Appellate Body members or hostility to adjudication under the Law of the Sea Convention, it is largely restricted to one or a few states. But in certain instances, such as public and private hostility to investor-state arbitration, it is much more pervasive. Resentment of, or second thoughts about, the value of international legal regimes is no longer restricted to familiar claims that international law and its institutions are too limited in scope, are ineffective, or embody only "Western" values or ideologies. Many are raising serious questions about whether, overall, the continued expansion of international legalization and institutionalization is good policy or should be curbed. The 1990s North Atlantic sensibility that international legal solutions or managerial regimes could and should be created by government or public-private action for most major global issues is now in radical eclipse. If major international legal institutions ranging from the UN and the WTO to the ICC and the International Tribunal for the Law of the Sea did not already exist, it is very unlikely that they would be created under current conditions. It is too soon to say whether the tide has really turned against legalized multilateral cooperation generally rather than there being merely a flux against some major manifestations of it; or whether a waning in intergovernmental governance will precipitate more active private governance or forms of public/private collaboration. But it is clear that earlier hopes for a cascade of new institutions to address global or regional threats, such as inequality, ecological sustainability, or cybersecurity and internet privacy, are profoundly challenged-both in and beyond the West.

While stability and basic national and international order, as well as particular international legal issues, loom large for leaders of the largest countries, including Prime Minister Modi and Presidents Putin, Trump, and Xi, it seems unlikely that they, or their highest advisers, will become centrally concerned with the production of international legal regimes. It is difficult now to imagine that a U.S. secretary of state would pause in office to personally write a book 
on international law. Yet James Madison did exactly this in 1806, producing a book on the international law of nonbelligerent maritime rights and neutrality. ${ }^{1}$ This reflected not only the urgent importance of the subject to the commerce and peace of the fledgling United States during the Britain-France Napoleonic wars, but also his confidence that expostulating and publicizing a well-grounded view of the subject congenial to American interests was a significant form of political action that might make a difference not only to international politics, but also to national policy coherence.

These displacements and decenterings of international law's recently dominant narrativecombined with the sheer acceleration of change in numerous areas of governance and politics, the transformation of information technology and media of expression, and the deluge of instantly available materials, commentaries, and scholarship-call for new thinking about the nature, role, and futures of traditional journals like this one.

One of the most significant recent changes for $A J I L$ is our dynamic presence in cyberspace through the specially designed and aptly named AJIL Unbound. Since its launch in 2014 with a series of essays on the U.S. Supreme Court's decision in Kiobel v. Royal Dutch Petroleum, this online and fully open access companion to AJIL has enabled the Journal to greatly expand its coverage, reach, and participation. By the end of volume 110, AJIL Unbound had published the work of 190 authors, many of whom had never previously contributed to $A J I L$, in symposia addressing a wonderfully rich and diverse range of topics, including some that had rarely or never previously been the subject of $A J I L$ attention. In volume 110 (2016-2017) alone, topics of symposia included responses to Devika Hovell's lead article on accountability of the UN, contemporary debates on Third World Approaches to International Law (TWAIL), the U.S. Supreme Court's RJR Nabisco v. European Community decision on extraterritoriality, discussion of Nienke Grossman's lead article on gender and representation on the benches of international tribunals, the centenary of the Sykes-Picot Agreement, the Third Restatement of the Conflict of Laws, the Colombian FARC peace agreements, international criminal tribunals, the South China Sea Arbitration, human shields, and cybersecurity.

Through the leadership of a committed subbody within the board of editors, led by Karen Knop, and under the oversight of Harlan Cohen and Melissa Durkee as its sterling managing editors, AJIL Unbound rapidly established a unique niche in the field. It publishes specially commissioned articles limited to a maximum of three thousand words, each fully peerreviewed, and subject to eventual approval by one of the editors in chief. Symposia topics and authors are designated by the AJIL Unbound committee. Thanks to the able efforts of Juergen Bering, AJIL Unbound articles are archived to correspond to the volume and issue numbers of the print $A J I L$, are fully downloadable in PDF form, and resemble, when in print, the pages of $A J I L$ itself. Some of the symposia included in AJIL Unbound have used lead articles and notes/comments carried in the print $A J I L$ as opportunities to begin broader conversations about the topics addressed by those pieces, including symposia on matters ranging from the views expressed by Todd Buchwald and Harold Hongju Koh on the treatment of aggression in the Statute of the International Criminal Court to Joost Pauwelyn's research on the background of trade versus investment adjudicators.

\footnotetext{
${ }^{1}$ James Madison, An Examination of the British Doctrine, Which Subjects to Capture a Neutral Trade, Not Open in Time of Peace (1806).
} 
The print version of $A J I L$ remains substantially similar in appearance to what emerged in 1907, but there have recently been some changes in its contents and method of production. As is suggested by Fleur Johns's lead article in this issue-which addresses some changes to ways of understanding and functioning in international law connected with new capacities of sensory technology — we have sought where we can to expand the range of topics and methods deemed apposite in a journal devoted to international law. Of course, AJIL continues to cover interstate institutions, rules, and processes, and their national legal and policy implications, but it increasingly also considers norms elaborated by and among diverse congeries of entities other than states and interstate institutions - including "private" institutions engaged in regulation affecting wider publics. The field encompasses doctrinally inclined lawyers engaged in parsing black letter rules, but also other kinds of practitioners and scholars, including those adept in economics and game theory, philosophy, anthropology, and various qualitative and quantitative empirical methods. We have recently published lead articles and notes/comments deploying each of these approaches or methods, while continuing AJIL's tradition of publishing the best articles available to us that address international law as classically understood. In 2013, we aligned $A J I L$ 's selection process for lead articles with the kind of double-blind peer review procedure that comparable faculty-edited journals in law and other disciplines use, and we introduced a formal structure for managing all consideration of manuscripts in cases in which one or both of us are recused, which includes submissions from institutional colleagues, individuals mentored by one or both of us, and previous coauthors.

Thanks to a set of reforms initiated by ASIL (under President Donald Donovan) and AJIL in 2013, we have engaged in a step-wise expansion of the number of $A J I L$ 's voting board of editors from twenty-five to thirty. ${ }^{2}$ Board service also has been reduced to four years, renewable once. Thanks to these efforts, as well as others, AJIL's entire board, including its honorary editors, is now comprised of more members of U.S. minorities, more women, and more scholars living abroad than at any time in its history. We think that these changes are more likely to enable $A J I L$ to stay abreast of a field that is no longer the tight-knit "invisible college" that the late Oscar Schachter once described-but we are not under any illusion that our board is sufficiently representative along various dimensions, including with regard to some major currents of opinion and outlook in the national politics of the United States and other states experiencing new tides of populism. Thanks to the board and to the work of a very talented team of law students as submissions editors at New York University, we now provide detailed feedback and suggestions to most authors who submit lead article manuscripts to us. Even when we reject manuscripts—as we regretfully most often do, given the scarcity of slots available and the robust peer review process-many prospective authors now receive substantive comments from us (and reviewers), and not merely a standard rejection letter. This feedback has often led to revisions that improve the paper and facilitate successful publication elsewhere.

While the print edition's various subsections, surveying the Contemporary Practice of the United States (CPUS), Book Reviews, and International Decisions, have broadly retained their long-established formats, since 2013 each of these sections has updated its coverage

\footnotetext{
${ }^{2}$ Honorary editors are those over the age of 65 who previously served on the regular board for a period of eight years and remain active; they continue to serve vital roles as peer reviewers of $A J I L$ submissions and in many other capacities, however they do not vote in board elections.
} 
in different ways. With vast amounts of material immediately accessible to anyone with unblocked access to the worldwide internet—but much misinformation, propaganda, and erroneous material woven into this mix and at times favored by internet search enginesAJIL's function is more than ever to provide well-informed insight, broad-gauged context, and accurate and reliable information. As press releases and reports issued by the U.S. Department of State and other U.S. and foreign government agencies and international institutions can readily be found online, our CPUS section no longer attempts comprehensive coverage, but has adopted a more selective approach. Under the leadership from 2013-2017 of Kristina Daugirdas and Julian Mortenson and students at the University of Michigan, CPUS items were increasingly likely to present a longer narrative covering a number of related actions - such as those involving the United States, China, and others in and around the South China Sea-that goes deeper on legally salient aspects than even the most erudite media outlets. Thanks to the inspiring efforts of our long-time Book Review editor, Richard Bilder, that section now includes a regular stream of longer, reflective essays that consider a single book or a cluster of books in a broader context. David Stewart, the editor of International Decisions, has continued to reach for an ever more diverse pool of authors, many not based in the United States, to select from what has been a fast-rising number of rulings issued by proliferating international adjudicative bodies and by national courts that are more engaged than ever with international law-and on occasion may inspire the forms of backlash noted above. ${ }^{3}$

All of this has hitherto been pursued within the constraints of self-publishing a scholarly journal with only limited resources to invest in internet platforms, marketing, open access, and all the other technical aspects of submissions management, copyediting, and production. The publishing partnership with Cambridge University Press thus represents a truly new era, with potential to liberate us from some of these constraints and to enable $A J I L$ and $A J I L$ Unbound to flourish in a dynamic environment in which the rapidity of change requires us all to add nimble adaptability, as well as far-sighted planning, to the solidity and quality for which $A J I L$ is known. Whereas traditional journals of learned societies have tended to focus their efforts on getting high-quality scholarship into print for members and a limited cadre of other readers, the new CUP platform enables us to add an immeasurably greater focus on reaching many more readers worldwide, often through different formats including social media and other online streams.

We are conscious of an immense mismatch between what $A J I L$ writes about and who it reaches and engages with, in the United States and worldwide. Informed discussions of international law's nature, promise, and flaws need to occur and reach beyond elite bubbles of experts to those who are affected by international law-negatively as well as positively-in addition to those whose professional lives are devoted to it. This mismatch can be ameliorated through measures to provide some content that is better adapted to emerging or potential readerships (including college and perhaps even secondary school students, experts in other fields, people in developing countries, and people without access to an institutional subscription), to ensure availability in formats that appeal to these readerships (including multimedia platforms and podcasts, as well as hyperlinks and supporting materials), cueing off and building on material through timely social media posts, and provision, where possible, of open

${ }^{3}$ Ingrid Wuerth will take over the International Decisions section from David Stewart during 2017. 
access (as we do already with the entirety of AJIL Unbound). None of us who are involved in the production of $A J I L$ or AJIL Unbound, or for that matter, who are active in ASIL or work for CUP, have answers to this conundrum, much less to the challenges facing international law. At the same time, we hope to make progress, and all ideas and suggestions are warmly invited.

The change in publisher also marks a transformation in copyediting arrangements. Meticulous line-editing by professional editors has historically been a hallmark of AJIL. Anna Ascher embodied this tradition-in earlier decades, copyediting entire issues herself as well as managing all of the correspondence. Recently ASIL managed a fragmented work flow among multiple excellent editors working on different portions, including Anna herself who remained the editor of the International Decisions section through 2016. Starting with this issue, copyediting is being undertaken mainly by a single senior editor, with another working on AJIL Unbound, both managed by CUP. As hitherto, the new team will confirm the substantive accuracy of all sources cited by our authors and make editorial suggestions to correct infelicities of grammar and to enhance readability. The new structure is expected to reduce costs of production (which had grown beyond ASIL's ability to absorb), and to increase the speed and punctuality of publication. As soon as articles are ready for publication, they will appear online through CUP's "FirstView" system, while AJIL will continue as a quarterly print publication. We also expect, over time, to increase the number of lead articles, notes/comments, and other material in each quarterly issue. AJIL Unbound is expected to continue publishing about twelve online symposia per year, with potential to expand in future.

We are endeavoring to ensure that these transitions result in no diminution in the quality of $A J I L$ or $A J I L$ Unbound. We remain very strongly committed to publishing scholarship that is likely to stand the test of time in both venues. We are acutely aware that transitions entail risks as well as opportunities, a reality for journals dependent on scholarly volunteers as much as it is for national political systems and international orders, and we expect bumps in the road. As we navigate this transition_and the far more significant ones that major political changes bring to international law and its institutions-we welcome your views both on the field and on AJIL's and AJIL Unbound's contributions.

José E. Alvarez 